\title{
STRATEGI PEMBELAJARAN BERORIENTASI KONSEP TRI HITA KARANA PADA FAKULTAS BAHASA DAN SENI UNIVERSITAS PENDIDIKAN GANESHA
}

\author{
Sang Ayu Putu Sriasih ${ }^{1}$, I Gede Budasi ${ }^{2}$ \\ Putu Kerti Nitiasih $^{3}$, Ni Made Rai Wisudariani ${ }^{4}$ \\ Fakultas Bahasa dan Seni, Universitas Pendidikan Ganesha Singaraja
}

\begin{abstract}
ABSTRAK
Penelitian ini bertujuan memperoleh data mengenai keterpahaman civitas akademika terhadap landasan Tri HIta Karana sebagai bagian dari visi Fakultas Bahasa dan Seni dan strategi pembelajaran berorientasi konsep Tri Hita Karana oleh para dosen di lingkungan Fakultas Bahasa dan Seni. Penelitian ini menggunakan rancangan deskriptif yang bersifat expostfacto dengan subjek penelitian para dosen, mahasiswa, dan pegawai di lingkungan Fakultas Bahasa dan Seni, Undiksha. Data penelitian dikumpulkan dengan metode studi dokumenter, metode observasi, dan metode angket. Analisis data dilakukan melalui empat tahap, yaitu (1) pengumpulan data, (2) reduksi data, (3) penyajian data, dan (4) penarikan simpulan. Hasil penelitian ini menunjukkan tingkat keterpahaman dosen, mahasiswa, dan pegawai di Fakultas Bahasa dan Seni terhadap visi fakultas tergolong sangat baik. Dalam pembelajaran, konsep Tri Hita Karana diimplementasikan oleh dosen dalam bagian perencanaan, pelaksanaan, maupun dalam kegiatan evaluasi pembelajaran. Konsep Tri Hita Karana diintegrasikan untuk melandasi setiap komponen strategi pembelajaran baik pada tahap perencanaan, pelaksanaan, maupun pada tahap evaluasi.
\end{abstract}

Kata-kata Kunci: strategi pembelajaran, Tri Hita Karana.

\begin{abstract}
This study aims to obtain data on the understanding of the academic community on the foundation of Tri Hita Karana as part of the vision of the Faculty of Language and Arts and the learning strategy which is oriented to the concept of Tri Hita Karana by lecturers in the Faculty of Language and Art. This study uses a descriptive design that is the expostfacto design. The research subjects are the lecturers in the Faculty of Language and Art, Undiksha. The data were collected using documentary study, observation, and questionnaire. Data analysis was carried out through four stages, namely (1) data collection, (2) data reduction, (3) data presentation, and (4) drawing conclusions. The results of this study indicate the level of understanding of lecturers, students, and employees at the Faculty of Language and Art towards the faculty vision is very good. In learning, the concept of Tri Hita Karana is implemented by lecturers in the planning, implementation
\end{abstract}


and learning evaluation activities. The Tri Hita Karana concept is integrated to underlie each component of the learning strategy at the planning, implementation and evaluation.

Key Words: learning strategies, Tri Hita Karana

\section{PENDAHULUAN}

Reformasi arah pengelolaan universitas dapat dilakukan dengan berlandaskan pada pilar budaya lokal. Sudira (2014) menyatakan bahwa untuk membangun sebuah perguruan tinggi dengan keunggulan yang unik dapat dilakukan dengan memperhatikan empat konteks utama pendidikan yaitu: (1) konteks lokal; (2) konteks nasional; (3) konteks regional; dan (4) konteks global. Di antara keempat konteks tersebut, konteks lokal adalah konteks yang paling memungkinkan bagi sebuah perguruan tinggi membangun keunikan sebagai keunggulannya, dengan syarat perguruan tinggi itu memiliki kearifan lokal yang baik dan adiluhung yang dapat digunakan sebagai basis pengembangan.

Kearifan lokal dapat menjadi kekuatan ketika pengetahuan dan praktikpraktiknya digunakan secara selaras dengan usaha pembangunan masyarakat, termasuk di dalam mengembangkan perguruan tinggi. Sebagai salah satu indigenous wisdom masyarakat Bali yang telah diakui oleh UNESCO, Tri Hita Karana adalah kristal bagi pengembangan pendidikan di Indonesia yang dapat dikembangkan secara global. Tri Hita Karana sangat baik digunakan sebagai framework pendidikan di Indonesia yang berfungsi sebagai penyaring pengaruh negatif globalisasi. Tri Hita Karana dapat digunakan sebagai penguat dan pemupuk tumbuhnya pendidikan yang mengakar kepada kearifan lokal dengan perspektif global untuk pembangunan pendidikan berkelanjutan. Beberapa pakar menjelaskan pengertian Tri Hita Karana sebagai berikut: tri = tiga, hita = kebahagiaan/ kemakmuran/ kesejahteraan, dan karana = penyebab. Jadi, Tri Hita Karana adalah tiga hal yang menyebabkan hubungan harmonis atau kebahagian hidup yakni hubungan manusia dengan Tuhan (parhyangan), hubungan manusia dengan manusia (pawongan), dan hubungan manusia dengan lingkungan 
(palemahan) (Wiana, 2004); (Sudarta, 2008); (Windia, 2011); dan (Wirawan, 2011).

Praksis indigenous wisdom, Tri Hita Karana ini pula yang menjadi dasar yang melandasi visi universitas maupun Fakultas Bahasa dan Seni. Visi dari Fakultas Bahasa dan Seni yang diturunkan dari visi lembaga yakni menjadi pusat unggulan (center of excellence) pengembangan bahasa dan seni, baik kependidikan dan nonkependidikan yang berbudaya dan humanis berlandaskan falsafah Tri Hita Karana. Visi ini memberi makna bahwa pendidikan di FBS Undiksha harus mampu membangun civitas akademika dengan tiga keharmonisan yaitu keharmonisan dengan sang Pencipta (Parahyangan), keharmonisan dengan sesama (Pawongan), dan keharmonisan dengan lingkungan (Palemahan).

Parhyangan merupakan hubungan yang bersifat vertikal, atau hubungan antara manusia dengan Tuhan sebagai sang pencipta. Hubungan ini merupakan wujud rasa syukur terhadap Tuhan Yang Maha Esa karena kesadaran kita semua bahwa segala sesuatunya berasal dari-Nya. Hubungan antara manusia dengan sesama (Pawongan). Pawongan merupakan hubungan yang baik antara manusia dengan manusia. Hubungan sosial yang baik akan menciptakan keharmonisan di antara sesama. Hubungan antara manusia dengan alam lingkungannya (unsur Palemahan). Palemahan merupakan hubungan antara manusia dengan alam. Hubungan ini merupakan suatu tanggung jawab sosial untuk menjaga lingkungan sebagai ciptaan Tuhan yang sangat agung (Windia, 2005).

Visi lembaga yang berlandaskan konsep Tri Hita Karana adalah pendidikan yang bertujuan menghasilkan luaran berkarakter dan berbudaya Tri Hita Karana. Pengembangan pendidikan yang dilandasi konsep Tri Hita Karana membutuhkan pembudayaan nilai-nilai luhur Tri Hita Karana sebagai basis pengembangan standar kompetensi lulusan, standar isi program, standar proses pembelajaran, standar penilaian, standar pendidik dan tenaga kependidikan, standar sarana-prasarana, standar pengelolaan, dan standar biaya. Pewujudnyataan visi ini sangat ditentukan oleh kemampuan lembaga dalam mengimplementasikan konsep ini secara terencana dan terprogram. Civitas akademika, baik mahasiswa, 
dosen, maupun tenaga kependidikan harus memahami bagaimana cara mewujudkan visi lembaga melalui tugas pokok yang dimiliki.

Keterpahaman civitas akademika terhadap visi misi lembaga merupakan aspek yang penting untuk dikaji secara mendalam. Bahkan dalam pengisian borang fakultas, aspek keterpahaman civitas akademika terhadap visi misi lembaga menjadi salah satu aspek penilaian. Salah satu indikator keterpahaman civitas akademika terhadap visi maupun misi lembaga adalah pemahaman sivitas akademika terhadap visi, misi fakultas yang tampak dalam bentuk kesadaran para sivitas akademika ketika menjalankan tugas-tugas akademis, seperti dalam proses pembelajaran, penelitian, dan pengabdian kepada masyarakat. Bagi dosen, pemahaman terhadap visi misi oleh dosen FBS Undiksha dicerminkan melalui pelaksanaan Tri Dharma Perguruan Tinggi.

Dalam proses pendidikan, implementasi konsep Tri Hita Karana dapat dituangkan oleh dosen dalam bagian perencanaan, pelaksanaan, maupun dalam kegiatan evaluasi pembelajaran. Implementasi ini memberikan suatu pengaruh terhadap hasil belajar, baik dalam aspek kognitif, aspek psikomotorik, maupun aspek afektif yang mampu memberikan tuntunan hidup kepada para mahasiswa. Selama ini, kajian terhadap sejauh mana implementasi Tri Hita Karana ini dituangkan dalam proses pendidikan belum ada. Oleh karena itu, penelitian ini merupakan penelitian yang penting untuk segera direalisasikan. Melalui penelitian ini, data mengenai keterpahaman civitas akademika dalam mengimplementasikan konsep Tri Hita Karana dalam bidang pendidikan dapat diperoleh.

Fokus permasalahan yang diangkat dalam kajian ini adalah (1) bagaimanakah keterpahaman civitas akademika terhadap visi misi fakultas? dan (2) bagaimanakah strategi para dosen Fakultas Bahasa dan Seni, Undiksha dalam mengimplementasikan konsep Tri Hita Karana dalam pembelajaran?

Secara umum penelitian ini bertujuan untuk mengetahui keterpahaman civitas akademika terhadap visi misi fakultas dan menganalisis strategi para dosen Fakultas Bahasa dan Seni, Undiksha dalam mengimplementasikan konsep Tri Hita Karana dalam pembelajaran. 
Penelitian ini diharapkan dapat memberikan setidaknya dua manfaat, yaitu berupa manfaat teoretis dan manfaat praktis. Manfaat teoretis berupa pemerkayaan khazanah ilmu pengetahuan, khususnya pada aspek implementasi pembelajaran dipadukan dengan konsep Tri Hita Karana. Selain itu, hasil penelitian ini diharapkan dapat memantapkan budaya adi luhur bangsa guna melandasi pendidikan di Indonesia yang berbudaya.

Manfaat praktis yang ditawarkan dalam penelitian ini berupa sumbangan bagi semua kalangan yang terlibat dalam pendidikan, antara lain (1) bagi dosen pengampu MK di lingkungan fakultas, hasil penelitian ini diharapkan dapat dijadikan bahan evaluasi dalam perkuliahan dengan melandasi pembelajaran yang dirancang dan dilakukan di dalam kelas dengan konsep Tri Hita Karana; dan (2) bagi pimpinan fakultas, penelitian ini dapat dijadikan masukan guna memonitoring tingkat keterpahaman civitas akademika terhadap visi misi lembaga yang dituangkan dalam bidang pendidikan: (3) bagi pihak Gugus Kendali Mutu Fakultas Bahasa dan Seni, hasil penelitian ini dapat digunakan sebagai bahan dalam pengisian borang terkait indikator keterpahaman civitas akademika FBS terhadap visi misi fakultas.

\section{METODE PENELITIAN}

Ada beberapa hal yang dibahas dalam metode penelitian ini yakni, rancangan penelitian, subjek dan objek penelitian, metode pengumpulan data, dan analisis data beserta prosedurnya. Penelitian ini termasuk ke dalam penelitian deskriptif yang bersifat expostfacto. Penelitian deskriptif-expostfacto bertujuan untuk memaparkan data sebagaimana adanya di mana peneliti tidak mempunyai kontrol langsung terhadap variabel-variabel bebas (independent variable) karena fenomena telah terjadi. Dalam hal ini, fenomena yang dimaksud adalah implementasi Konsep Tri Hita Karana dalam Bidang Akademik di Fakultas Bahasa dan Seni, Universitas Pendidikan Ganesha. Data yang dideskripsikan adalah data-data yang berkaitan dengan implementasi Konsep Tri Hita Karana 
dalam perencanaan, pelaksanaan, dan Tri Hita Karana dalam evaluasi pembelajaran.

Subjek penelitian ini adalah para dosen, mahasiswa, dan pegawai di lingkungan Fakultas Bahasa dan Seni, Undiksha. Dosen yang menjadi subjek dalam penelitian ini dipilih secara acak guna mewakili masing-masing jurusan/program studi dengan perhitungan lima orang dosen setiap jurusan/prodi sehingga ada 35 responden, mahasiswa dari prodi tergemuk diambil 15, 10, sampai 5 orang dan totalnya 50 orang; sedangkan untuk pegawai dari 30 kuisioner yang kembali adalah 20. Objek yang dikaji dalam penelitian ini adalah implementasi Konsep Tri Hita Karana dalam perencanaan, pelaksanaan, maupun evaluasi pembelajaran yang dilakukan oleh dosen dalam perkuliahan.

Metode pengumpulan data adalah cara-cara yang digunakan peneliti untuk mengumpulkan data. Penelitian ini menggunakan tiga metode pengumpulan data, yaitu (1) metode studi dokumenter, (2) metode observasi, dan (3) metode angket. Metode Studi Dokumenter digunakan untuk mengumpulkan data-data yang berkaitan dengan pengembangan perencanaan pembelajaran yang dilakukan oleh para dosen baik dalam bentuk silabus maupun satuan acara perkuliahan (SAP) atau rencana program semester (RPS). Instrumen untuk metode studi dokumenter (terlampir).

Metode kedua adalah metode observasi. Data-data yang dikumpulkan dengan metode ini adalah data yang berkaitan dengan pelaksanaan pembelajaran yang dilakukan oleh dosen di dalam kelas. Teknik observasi yang dilakukan berupa teknik observasi nonpartisipasi. Peneliti hanya sebagai pengamat dan tidak terlibat langsung dalam proses belajar-mengajar. (Pedoman observasi terlampir). Metode angket digunakan untuk mengetahui implementasi Konsep Tri Hita Karana dalam perencanaan, pelaksanaan, dan evaluasi pembelajaran, yang dilakukan oleh dosen dalam pembelajaran. Instrumen angket terlampir.

Analisis data dalam penelitian ini mengadaptasi prosedur analisis data kualitatif model interaktif Miles dan Huberman (1922: 21-25). Analisis data dengan menggunakan model tersebut mencakup empat tahap, yaitu (1) pengumpulan data, (2) reduksi data, (3) penyajian data, dan (4) penarikan 
simpulan. Semua tahap tersebut memiliki keterkaitan proses antara satu dengan yang lainnya. Secara jelas, hal tersebut dipaparkan seperti berikut ini.

Sesuai dengan metode pengumpulan data, dalam penelitian ini digunakan tiga cara pengumpulan data, yaitu pengumpulan data yang dilakukan dengan metode studi dokumenter, observasi, dan angket. Hasil pengumpulan data tersebut berupa hasil analisis dokumen yang dilakukan, hasil observasi, dan angket. Data yang telah terkumpul, kemudian dianalisis lebih lanjut.

Reduksi data adalah memilih data yang diperlukan dan menyisihkan datadata yang kurang penting. Data yang kurang penting dipertimbangkan lagi bila diperlukan. Reduksi data dilakukan mulai dari pengumpulan data di lapangan hingga analisis setelah data terkumpul. Dalam penelitian ini, reduksi data setelah terkumpul dilakukan dengan cara seperti berikut. Data berupa implementasi Konsep Tri Hita Karana dalam perencanaan, pelaksanaan, dan evaluasi yang dilakukan oleh dosen dibaca dengan cermat. Demikian pula data dari mahasiswa dan pegawai dibaca secara cermat. Bersamaan dengan kegiatan tersebut, reduksi data dilakukan melalui proses identifikasi data dan klasifikasi data dengan paparan seperti berikut.

\section{Identifikasi data}

Identifikasi data yang dilakukan lebih kepada mengenali data-data yang memang harus dievaluasi dan data-data yang tidak harus dievaluasi. Contohnya adalah ketika mengevaluasi implementasi Konsep Tri Hita Karana dalam perencanaan pembelajaran ternyata dosen menambahkan komponen-komponen lain yang tidak berhubungan dengan komponen yang dapat diintegrasikan dengan konsep Tri Hita Karana, maka komponen-komponen yang lebih itu peneliti sisihkan.

\section{Klasifikasi Data}

Setelah diidentifikasi, data-data selanjutnya ditata dan diklasifikasikan sesuai dengan masalah yang dikaji, yaitu (1) implementasi Konsep Tri Hita Karana dalam perencanaan pembelajaran, (2) implementasi Konsep Tri Hita Karana dalam pelaksanaan pembelajaran, dan (3) implementasi Konsep Tri Hita 
Karana dalam evaluasi pembelajaran. Klasifikasi dilakukan melalui pengelompokan data-data yang terkumpul ke dalam tiga kelompok.

3. Penyajian Data

Setelah data-data melewati proses reduksi, hasil penelitian disajikan secara deskriptif kualitatif. Data tersebut digambarkan dengan menggunakan uraian naratif ataupun penggambaran dengan menggunakan kata-kata. Data-data yang dianalisis dengan teknik kualitatif dapat diamati pada tabel berikut ini.

Tabel 3.1 Penyajian Data

\begin{tabular}{|l|l|l|}
\hline No. & \multicolumn{1}{|c|}{ Data } & \multicolumn{1}{|c|}{$\begin{array}{c}\text { Teknik analisis } \\
\text { data }\end{array}$} \\
\hline 1. & $\begin{array}{l}\text { Implementasi Konsep Tri Hita Karana dalam } \\
\text { perencanaan pembelajaran }\end{array}$ & Kualitatif \\
\hline 2. & $\begin{array}{l}\text { Implementasi Konsep Tri Hita Karana dalam } \\
\text { pelaksanaan pembelajaran }\end{array}$ & Kualitatif \\
\hline 3. & $\begin{array}{l}\text { Implementasi Konsep Tri Hita Karana dalam } \\
\text { evaluasi pembelajaran }\end{array}$ & Kualitatif \\
\hline
\end{tabular}

Langkah terakhir dalam analisis data adalah penarikan simpulan yang didasarkan pada hasil/temuan pada proses penyajian data. Simpulan yang dibuat diharapkan dapat memberikan jawaban atas masalah penelitian.

\section{HASIL DAN PEMBAHASAN}

\section{Hasil Penelitian}

Responden dalam survei ini adalah 35 orang dosen Fakultas Bahasa dan Seni (setiap jurusan disampel oleh lima orang dosen), 20 orang tenaga kependidikan, dan 50 orang mahasiswa. Hasil penelitian ini menunjukkan bahwa keterpahaman civitas akademika (tingkat keterpahaman visi misi dosen $(85,5)$, mahasiswa (86), dan tenaga kependidikan $(87,5)$ ) terhadap visi misi fakultas 
tergolong sangat baik. Konsep Tri Hita Karana dapat diimplementasikan dalam pembelajaran oleh para dosen di Fakultas Bahasa dan Seni, Undiksha.

Hasil kajian ini menunjukkan strategi pembelajaran di perguruan tinggi yang meliputi perencanaan proses pembelajaran, pelaksanaan pembelajaran, evaluasi atau penilaian hasil belajar, dan pengawasan dan penilaian pembelajaran, dapat diintegrasikan dengan konsep Tri Hita Karana untuk melandasi setiap komponen strategi pembelajaran baik pada tahap perencanaan, pelaksanaan, maupun pada tahap evaluasi.

a. Perencanaan Pembelajaran

Secara umum, mekanisme penyusunan perencanaan pembelajaran yang dilakukan oleh dosen sebagai berikut.

1. Dosen menyusun silabus semua mata kuliah yang diampunya. Silabus mata kuliah terdiri atas unsur-unsur: identitas mata kuliah, standar kompetensi, materi pokok, jenis penilaian, dan referensi.

2. Dosen menyusun SAP/RPS mata kuliah yang diampunya. SAP/RPS mata kuliah terdiri atas unsur-unsur: identitas mata kuliah, waktu pertemuan, standar kompetensi, indikator pencapaian kompetensi, materi pembelajaran, kegiatan belajar-mengajar, bentuk penilaian, jumlah jam pelajaran, dan sumber belajar.

3. Dosen menyusun instrumen penilaian hasil belajar mahasiswa yang terdiri atas: tugas, soal, kunci jawaban, dan rubrik penilaian sesuai dengan karakteristik mata kuliah.

4. Dosen meminta masukan terhadap perencanaan pembelajaran yang telah dibuat kepada dosen lain dalam satu bidang keahlian.

5. Dosen memperbaiki dokumen perencanaan pembelajaran yang telah dibuat, menandatangani, dan memohon tanda tangan pengesahan kepada ketua jurusan/ prodi.

b. Pelaksanaan Pembelajaran

Mekanisme pelaksanaan pembelajaran adalah sebagai berikut. 
1. Dosen memulai dan mengakhiri pembelajaran dengan memimpin doa bersama.

2. Dosen meminta mahasiswa memperhatikan lingkungan ruang kuliah dan jika masih ada sampah, mahasiswa dan dosen membersihkan ruang kelas terlebih dahulu.

3. Dosen menyampaikan perencanaan pembelajaran dan urgensinya kepada seluruh mahasiswa peserta kuliah.

4. Dosen memberikan kesempatan kepada mahasiswa untuk menanya, memberi tanggapan/usulan atas rencana pembelajaran yang dibuat dosen.

5. Dosen dan mahasiswa membuat kesepakatan pelaksanaan pembelajaran sebagai bentuk kontrak perkuliahan sesuai dengan perencanaan pembelajaran dan masukan yang diberikan mahasiswa.

6. Dosen melaksanakan pembelajaran sesuai dengan perencanaan pembelajaran yang telah disepakati bersama.

7. Dosen mengisi jurnal perkuliahan setiap kali memberikan kuliah/ praktikum

8. Mahasiswa menandatangani daftar hadir setiap mengikuti perkuliahan.

9. Mahasiswa mengikuti pelaksanaan pembelajaran sesuai dengan perencanaan pembelajaran yang telah disepakati bersama.

10. Dosen mengakhiri pembelajaran dalam satu semester dengan menandatangani jurnal perkuliahan.

11. Koordinator tingkat (korti) mahasiswa menyerahkan jurnal perkuliahan kepada ketua jurusan/prodi.

c. Penilaian Proses dan Hasil Belajar Mahasiswa

Mekanisme penilaian hasil belajar mahasiswa adalah sebagai berikut.

1. Dosen melakukan penilaian proses pembelajaran sesuai dengan kontrak penilaian yang disepakati dalam SAP/RPS.

2. Dosen memberikan lembaran soal (UTS/UAS) atau tugas kepada mahasiswa yang harus dikerjakan sesuai dengan petunjuk yang diberikan.

3. Mahasiswa mengerjakan soal (UTS, UAS) atau tugas yang diberikan dosen sesuai dengan petunjuk yang diberikan. 
4. Mahasiswa mengumpulkan hasil pekerjaannya sesuai dengan petunjuk yang diberikan.

5. Dosen mengoreksi dan memberi skor/nilai hasil pekerjaan mahasiswa sesuai dengan kunci jawaban/rubrik penilaian yang telah dibuat.

6. Dosen memasukkan skor/nilai hasil pekerjaan yang diperoleh mahasiswa ke dalam daftar penilaian hasil belajar mahasiswa.

7. Dosen mengembalikan hasil koreksi pekerjaan mahasiswa untuk dikoreksi kembali oleh mahasiswa.

8. Dosen merevisi skor/nilai yang diperoleh mahasiswa apabila terjadi kekeliruan penyekoran/penilaian.

9. Dosen memasukkan skor/nilai ke dalam daftar peserta kuliah dan nilai akhir (DPNA) di akhir semester.

d. Pengawasan dan Penilaian Pembelajaran

Mekanisme pengawasan dan penilaian pembelajaran adalah sebagai berikut.

1. Ketua jurusan/prodi memerintahkan dosen untuk mengumpulkan program perencanaan pembelajaran (Silabus dan SAP/RPS) di jurusan/prodi.

2. Ketua jurusan/prodi melakukan pengamatan pelaksanaan pembelajaran melalui pegecekan jurnal perkuliahan.

3. Ketua jurusan/prodi memerintahkan dosen untuk mengumpulkan instrumen penilaian hasil belajar mahasiswa ke jurusan/prodi.

4. Ketua jurusan/prodi menegur dosen yang belum melaksanakan perkuliahan sesuai dengan kontrak kuliah yang dibuatnya.

5. UJM melakukan Audit Mutu Internal (AMI) proses pembelajaran.

6. UJM melaporkan hasil AMI kepada pimpinan universitas/fakultas/ jurusan/prodi.

7. Universitas/fakultas/jurusan/prodi melakukan tindak lanjut atas hasil AMI proses perbelajaran tiap-tiap mata kuliah maupun kelompok mata kuliah. 
Berikut dipaparkan beberapa strategi yang digunakan oleh para dosen dalam mengimplementasikan konsep Tri Hita Karana dalam pembelajaran.

\begin{tabular}{|c|c|c|c|}
\hline Strategi & Parahyangan & Pawongan & Pelemahan \\
\hline Perencanaan & $\begin{array}{l}\text { 1. Memasukkan } \\
\text { sikap religius } \\
\text { dalam penyusunan } \\
\text { perangkat } \\
\text { pembelajaran }\end{array}$ & $\begin{array}{l}\text { 1. Memasukkan } \\
\text { sikap sosial dalam } \\
\text { penyusunan } \\
\text { perangkat } \\
\text { pembelajaran }\end{array}$ & $\begin{array}{l}\text { 1. Memasukkan sikap } \\
\text { menghargai } \\
\text { lingkungan dalam } \\
\text { penyusunan } \\
\text { perangkat } \\
\text { pembelajaran }\end{array}$ \\
\hline Pelaksanaan & 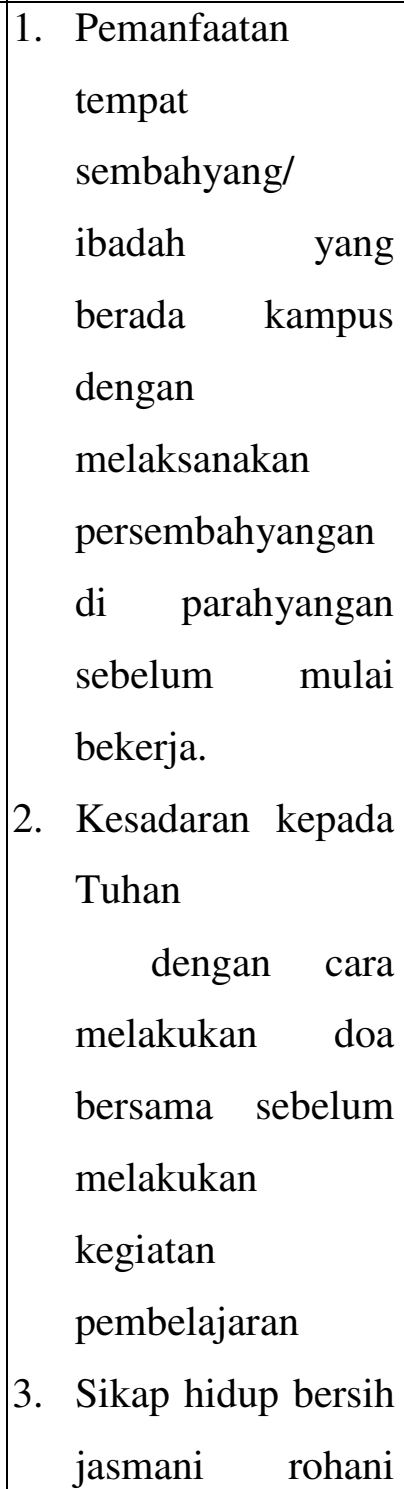 & 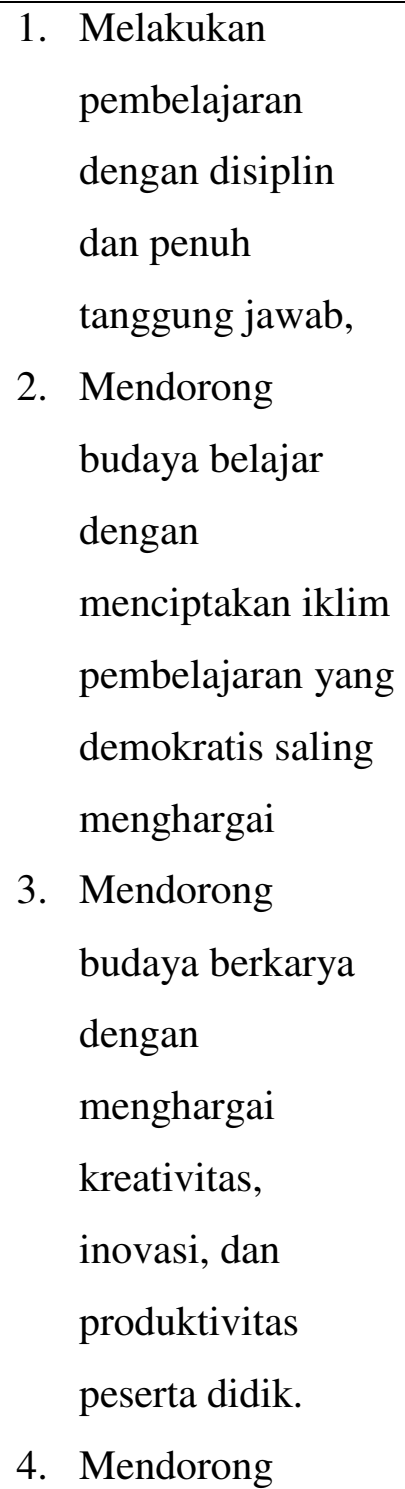 & $\begin{array}{l}\text { 1. Pelestarian alam } \\
\text { dengan } \\
\text { menghimbau } \\
\text { mahasiswa } \\
\text { menanam dan } \\
\text { merawat tanaman } \\
\text { 2. Pemeliharaan } \\
\text { bangunan kampus } \\
\text { dengan cara } \\
\text { mengajak } \\
\text { mahasisiwa } \\
\text { menjaga dan } \\
\text { menegor } \\
\text { mahasiswa yang } \\
\text { mencorat coret } \\
\text { bangunan kampus. } \\
\text { 3. Pemeliharaan } \\
\text { fasilitas kampus } \\
\text { dengan cara efektif } \\
\text { daan efisien dalam } \\
\text { menggunakan }\end{array}$ \\
\hline
\end{tabular}




\begin{tabular}{|c|c|c|c|c|c|}
\hline & 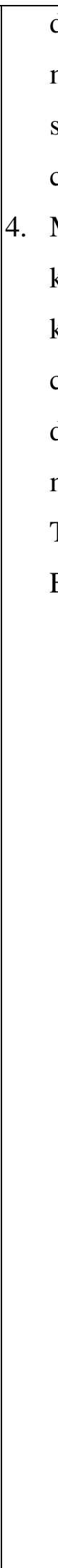 & $\begin{array}{l}\text { dengan cara } \\
\text { menghargai } \\
\text { sesama sebagai } \\
\text { ciptaan Tuhan } \\
\text { Menumbuhkan } \\
\text { keimananan dan } \\
\text { ketakwaan dengan } \\
\text { cara menghayati } \\
\text { diri sebagai } \\
\text { mahluk ciptaan } \\
\text { Tuhan Yang Maha } \\
\text { Esa }\end{array}$ & 5. & $\begin{array}{l}\text { budaya melayani } \\
\text { dengan penuh } \\
\text { keterbukaan, } \\
\text { komunikasi yang } \\
\text { efektif dan santun. } \\
\text { Menyediakan } \\
\text { ruang diskusi yang } \\
\text { demokratis } \\
\text { Menggunakan } \\
\text { teknologi untuk } \\
\text { menjalin } \\
\text { komunikasi yang } \\
\text { baik denagn } \\
\text { mahasisiwa } \\
\text { melalui } \\
\text { penyediaan } \\
\text { internet, alat } \\
\text { pengeras suara, } \\
\text { telepon, papan } \\
\text { pengumuman/ } \\
\text { informasi } \\
\text { Mengembangkan } \\
\text { rasa toleransi di } \\
\text { antara peserta } \\
\text { didik melalui } \\
\text { kegiatan diskusi. } \\
\text { Mensosialisasikan } \\
\text { terus pentingnya } \\
\text { keselasaran } \\
\text { pikiran, perkataan, } \\
\text { dan tindakan }\end{array}$ & $\begin{array}{l}\text { listrik, AC, } \\
\text { maupun LCD. } \\
\text { 4. Menjaga } \\
\text { kebersihan kelas } \\
\text { dengan cara } \\
\text { memerhatikan } \\
\text { kebersihan kelas } \\
\text { sebelum dan } \\
\text { setelah } \\
\text { pembelajaran dan } \\
\text { jika kelas belum } \\
\text { bersih peserta didik } \\
\text { dan dosen } \\
\text { membersihkan } \\
\text { kelas sebelum } \\
\text { pembelajaran } \\
\text { dimulai. } \\
\text { 5. Membuang sampah } \\
\text { pada tembat yang } \\
\text { telah disediakan. }\end{array}$ \\
\hline
\end{tabular}




\begin{tabular}{|c|c|c|c|}
\hline & & $\begin{array}{l}\text { dalam setiap } \\
\text { aktivitas } \\
\text { pembelajaran } \\
\text { 9. Penerapan nilai } \\
\text { kesopanan melalui } \\
\text { cara berpakain dan } \\
\text { potongan rambut } \\
\text { 10. Mentaati tata } \\
\text { tertib untuk } \\
\text { menghindari } \\
\text { adanya kekerasan } \\
\text { 11. Memberi apresiasi } \\
\text { dan penghargaan } \\
\text { bagi mahasisiwa } \\
\text { yang berprestasi } \\
\text { 12. Menumbuhkan } \\
\text { rasa saling } \\
\text { menghargai dan } \\
\text { mencintai satu } \\
\text { sama lain }\end{array}$ & \\
\hline Evaluasi & 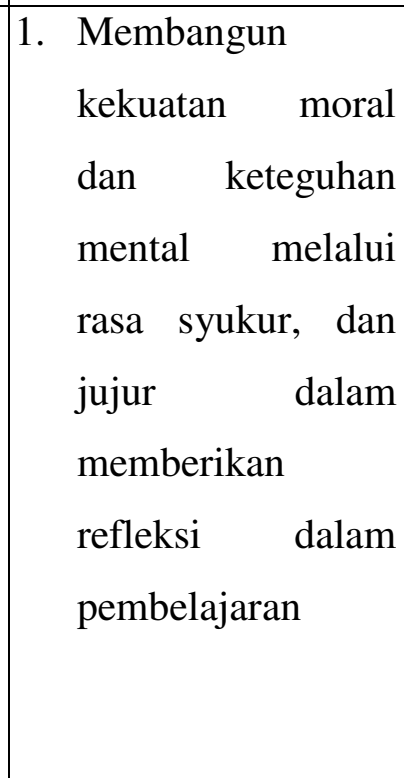 & 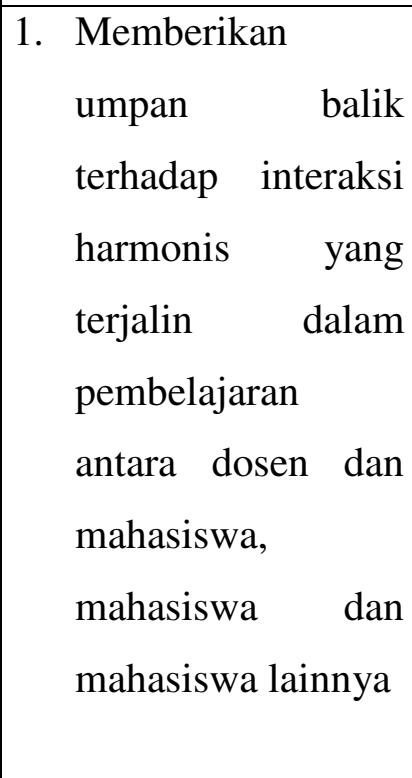 & $\begin{array}{l}\text { 1. } \text { Memberikan } \\
\text { umpan balik } \\
\text { terhadap upaya } \\
\text { pemeliharaan } \\
\text { lingkungan kampus } \\
\text { dengan cara } \\
\text { menjaga kelas tetap } \\
\text { bersih sebelum } \\
\text { maupun setelah } \\
\text { perkuliahan } \\
\text { berlangsung. }\end{array}$ \\
\hline
\end{tabular}




\section{Pembahasan}

Berdasarkan hasil penelitian tersebut, hal-hal yang dibahas dalam subbab ini meliputi tingkat keterpahaman civitas akademika terhadap visi misi fakultas dan pengimplementasian konsep Tri Hita Karana dalam pembelajaran. Masingmasing bahasan dipaparkan sebagai berikut.

Hasil penelitian ini menunjukkan, keterpahaman civitas akademika di Fakultas Bahasa dan Seni tergolong sangat baik. Berbagai sosialisasi visi misi yang dilakukan baik melalui media cetak, media elektronik, maupun dalam kegiatan rapat, serta kegiatan ilmiah lainnya memberikan pemahaman kepada civitas akademika tentang visi dan misi fakultas. Semakin sering sosialisasi dilakukan semakin paham civitas akademika dengan visi misi. Visi misi fakultas yang singkat juga mudah diingat oleh civitas akademika. Selain itu, pengelola program studi dan semua dosen mempunyai komitmen untuk menyosialisasikan visi misi kepada pihak-pihak terkait. Hal ini menyebabkan pemahaman sivitas akademika terhadap visi misi fakultas sangat baik.

Temuan kedua dalam penelitian ini terkait dengan pengimplementasian konsep Tri Hita Karana dalam pembelajaran. Pencantuman Tri Hita Karana dalam visi fakultas membawa konskwensi logis bagi seluruh sivitas untuk memahami nilai-nilai substansi yang terkadung dalam Tri Hita Karana. Civitas juga berupaya mengembangkan strategi implementasinya dalam berbagai pengembangan kebijakan Tri Dharma Perguruan Tinggi di Universitas Pendidikan Ganesha. Dalam konteks pelaksanaan pendidikan sebagai salah satu dari Tri Dharma Perguruan Tinggi, Visi ini menuntut dosen untuk mengembangkan inovasi pembelajaran berlandaskan falsafah Tri Hita Karana, utamanya dalam hal ini pembelajaran.

Implementasi konsep Tri Hita Karana dalam pembelajaran dapat diterapkan dalam proses perencanaan, pelaksanaan pembelajaran, dan penilaian hasil belajar. Implementasi transformasi perencanaan, pelaksanaan, dan penilaian khususnya pada dharma pertama harus dijiwai oleh falsafah Tri Hita Karana yang 
merupakan nilai local genius budaya Bali. Dalam implementasi transpormasi pembelajarannya, bahan kajian harus dalam balutan Tri Hita Karana. Pengembangan pembelajaran semacam itu sangat penting diupayakan, baik karena tuntutan visi dari universitas maupun tuntutan faktual masyarakat Indonesia yang multikultur (Lubis, 2006; Parekh, 2008; Kawuryan, 2009; Joel, 2016). Dalam konteks proses pembelajaran, dosen dapat menumbuhkan kemampuan berpikir kritis secara holistik yang mengimplementasikan: kecerdasan intelektual, sosial, spiritual, dan ekologis.

Model Pembelajaran berlandaskan Falsafah Tri Hita Karana di FBS dapat terlaksana dengan baik dan efektif. Model ini dapat berjalan sesuai dengan rencana, karena pemahaman dosen yang bagus tentang konsep model pembelajaran berlandaskan falsafah Tri Hita Karana, penguasaan dosen tentang nilai-nilai pada falsafah Tri Hita Karana, keterampilan dosen dalam melaksanakan model pembelajaran berlandaskan falsafah Tri Hita Karana, dan permasalahan kontekstual yang memuat nilai-nilai Tri Hita Karana.

Sistem sosial yang dianut model pembelajaran berlandaskan nilai-nilai Tri Hita Karana adalah Law structure (student centered learning). Artinya, model Pembelajaran MPK Berlandaskan Nilai-nilai Tri Hita Karana memposisikan mahasiswa sebagai pusat pembelajaran, menjunjung tinggi kehidupan sosial dan memperhatikan perbedaan individu. Penekanan dalam Model Pembelajaran berlandaskan Nilai-nilai Tri Hita Karana adalah konstruktivis. Oleh karena itu, dalam model pembelajaran berlandaskan Nilai-nilai Tri Hita Karana mahasiswa diberi kesempatan secara maksimal untuk mengkonstruksi pengetahuannya sendiri dengan kemampuan yang dimiliki masing-masing, dan dosen memposisikan diri sebagai fasilitator dan mediator.. Hasil penelitian ini sejalan dengan pemikiran Joyce, et al. (1992), bahwa sistem sosial menggambarkan aturan dan hubungan antara mahasiswa dengan dosen dan jenis norma yang disepakati. Kegiatan pembelajaran yang dilakukan menimbulkan interaksi timbal balik antara dosen dan mahasiswa. Interaksi pada Pembelajaran berlandaskan Nilai-nilai Tri Hita Karana akan mengukuhkan hubungan dosen dan mahasiswa sebagai individu yang saling mempercayai. 
Sistem sosial dalam model pembelajaran berlandaskan falsafah Tri Hita Karana dicirikan oleh tercerminnya nilai-nilai Tri Hita Karana di dalam interaksi yang terjadi di dalam proses pembelajaran. Adapun insersi nilai-nilai Tri Hita Karana tersebut dapat terjadi seperti saling mengakui keberadaan teman dan menghargai kemampuan teman/toleran, berpegang pada etika, bahasa yang santun dan mengembangkan sikap sosial dalam kelompok untuk meraih prestasi sesuai dengan kemampuan masing-masing. Setiap orang menyadari bahwa masingmasing memiliki kekurangan-kekurangan (kesadaran akan potensi diri) sehingga timbul rasa saling membantu satu dengan lainnya. Saling mengamalkan perilaku jujur, disiplin, tanggung jawab, peduli, santun, ketundukhatian, melakukan refleksi, proaktif dalam setiap proses pembelajaran. Memanfaatkan lingkungan sebagai sumber belajar dan melatih keterampilan.

Dalam aspek penilaian, penilaian terhadap proses dan hasil belajar mahasiswa dalam pembelajaran berlandaskan nilai-nilai falsafah Tri Hita Karana dilakukan terhadap dampak instruksional maupun dampak pengiring. Penilaian terhadap dampak instruksional dari internalisasi nilai-nilai falsafah Tri Hita Karana dilakukan secara terintegrasi dengan penilaian konten; sedangkan dampak pengiringnya dilakukan dalam bentuk penilaian dalam proses pembelajaran (penilaian sikap dan partisipasi).

Temuan ini sesuai dengan pendapat Dantes (2017) yang menyatakan bahwa dampak instruksional mencerminkan pencapaian CP sikap yang ditetapkan sebelumnya. Untuk menilainya, dapat dilakukan bersama-sama dengan penilaian materi kajian yang dipelajari dengan menggunakan rubrik penilaian dan instrument penilaian lain yang relevan. Dampak pengiring dinilai dalam proses pembelajaran, di mana nilai-nilai Tri Hita Karana digunakan untuk memfasilitasi proses pembelajaran. Penilaian dilakukan dengan observasi dan cara lain yang relevan. Penilaian dampak pengiring ini diharapkan menjadi data untuk unsur penilaian sikap dan partisipasi dalam Kurikulum Undiksha 2016. 


\section{SIMPULAN DAN SARAN}

Hasil kajian ini menunjukkan keterpahaman civitas akademika, baik mahasiswa, dosen, maupun tenaga kependidikan tergolong sangat baik. Tingkat pemahaman ini berimbas pada implementasi civitas akademika dalam mewujudkan visi Prodi melalui tugas pokok yang dimiliki. Dalam strategi pembelajaran, implementasi konsep Tri Hita Karana dapat dituangkan oleh dosen dalam bagian perencanaan, pelaksanaan, maupun dalam kegiatan evaluasi pembelajaran.

Bagi civitas akademika, praksis indigenous wisdom, Tri Hita Karana menjadi dasar yang melandasi visi dan misi fakultas. Visi ini memberi makna bahwa pendidikan di Fakultas harus mampu membangun sivitas akademika dengan tiga keharmonisan yaitu keharmonisan dengan sang Pencipta (Parahyangan), keharmonisan dengan sesama (Pawongan), dan keharmonisan dengan lingkungan (Palemahan). Pewujudnyataan visi ini sangat ditentukan oleh kemampuan civitas akademika dalam mengimplementasikan konsep ini secara terencana dan terprogram.

\section{Daftar Pustaka}

Dantes, Nyoman. 2017. Model Pembelajaran MPK berlandaskan Falsafah Tri Hita Karana. Makalah disampaikan dalam penyamaan persepsi MKU.

Joel Kahn, S. (2016). Kultur, Multikultur, Postkultur, Keragaman Budaya dan Imperialisme Kapitalisme Global. Jln. Ringroad Barat. INDeS.

Kawuryan, Sekar Purbarini. (2009). Bahan Ajar Mata Kuliah Pendidikan Multikultural. Yogyakarta: UNY.

Lubis, Nur A. Fadhil. (2006). Multikulturalisme dalam Politik. Jurnal Antropologi Sosial Budaya, Vol II.No. 1 April 2006. Medan USU

Mohamad Nazir. 2011. Metode Penelitian, Edisi ke 7. Bogor: Ghalia Indonesia Norr Juliansyah. 2010. Metodologi Penelitian. Jakarta: kencana.

Parekh, Bhikhu. (2008). Rethinking Multiculturalism Keberagaman Budaya dan Teori Politik. Yogyakarta: Kanisius. 
Sudira, Putu. 2013. Indigenous Wisdom Tri Hita Karana dan Pengembangan SDI Melalui SMK. Proseding LPPM UNY

Sudira, Putu. 2014. Konsep dan Praksis Pendidikan Hindu Berbasis Tri Hita Karana. Makalah Seminar Eksistensi Pendidikan Hindu dalam Sisdiknas di Era Global, PPs IHDN Denpasar, 8 Mei 2014.

Wiana, I Ketut. 2004. Tri Hita Karana Menurut Konsep Hindu. Suirabaya: Paramitha.

Windia,W.2005.'THK dan Pariwisata Berkelanjutan", dalam Buku Panduan THK Awards and Accreditation tahun 2005, Green Paradise, Denpasar.

Windia, Wayan. dan Ratna Komala Dewi, 2011. Analisis Bisnis Berlandaskan Tri Hita Karana. Denpasar: Udayana University Press.

Wirawan, I Made Adi. 2011. Tri Hita Karana Kajian Teologi Sosiologi dan Ekologi Menurut Veda. Surabaya: Paramitha. 